\title{
PENGEMBANGAN MULTIMEDIA PEMBELAJARAN UNTUK MENINGKATKAN PENGUASAAN KALA LAMPAU BAHASA PRANCIS MAHASISWA
}

\author{
Siti Sumiyati, Herman Dwi Surjono \\ Fakultas Bahasa dan Seni UNY, Universitas Negeri Yogyakarta \\ sitisumiyati@uny.ac.id, hermansurjono@uny.ac.id
}

\begin{abstract}
Abstrak
Penelitian ini bertujuan menguji kelayakan software pembelajaran kala lampau bahasa Prancis yang dihasilkan untuk mahasiswa Jurusan Pendidikan Bahasa Prancis FBS UNY, dan mengetahui peningkatan penguasaan kala lampau bahasa Prancis mahasiswa Jurusan Pendidikan Bahasa Prancis FBS UNY yang menggunakan produk multimedia pembelajaran yang dihasilkan. Model penelitian dan pengembangan ini dilakukan melalui tiga tahap, yaitu perencanaan, desain dan pengembangan. Proses validasi terhadap produk dilakukan dengan tahap uji alpha, uji beta dan uji coba produk. Hasil penelitian menunjukkan bahwa: (1) produk yang dihasilkan ini termasuk dalam kategori baik; (2) pembelajaran kala lampau dengan produk yang dihasilkan dapat meningkatkan penguasaan kala lampau bahasa Prancis mahasiswa dengan perolehan rerata gain score sebesar 0,59. Dengan demikian, disimpulkan bahwa multimedia pembelajaran yang dihasilkan layak digunakan dan efektif.
\end{abstract}

Kata kunci: multimedia pembelajaran, kala lampau bahasa prancis

\section{DEVELOPING INSTRUCTIONAL MULTIMEDIA TO IMPROVE STUDENTS' MASTERY OF FRENCH PAST TENSES}

\author{
Siti Sumiyati, Herman Dwi Surjono \\ Fakultas Bahasa dan Seni UNY, Universitas Negeri Yogyakarta \\ sitisumiyati@uny.ac.id, hermansurjono@uny.ac.id
}

\begin{abstract}
This study aimed at examining the feasibility of the developed instructional software of French past tenses for French Education Department Students, and determining increases in the French Education Department Students achievement who used the developed instructional multimedia product. It applied the research and development with 3 stages, i.e.: planning, design, and development. The process of validation of this product was carried out through 3 stages, i.e.: alpha testing, beta testing and product testing. The results of this study were that: (1) this developed product belongs to the good category; (2) learning French past tenses with this product could improve students' mastery of French past tenses, and achieved an average normalized gain score 0,59. Therefore, it was concluded that the developed product was feasible and effective.
\end{abstract}

Keywords: instructional multimedia, French past tenses 


\section{Pendahuluan}

Berdasarkan buku pedoman penggunaan dengan buku ajar yang digunakan di Jurusan Pendidikan Bahasa Prancis, pembelajaran tata bahasa Prancis menggunakan metode induktif (Girardet \& Pêcheur, 2004, p.7). Hal ini senada dengan pernyataan Centre Européen Commun Références pour les Langues (CECRL) bahwa pembelajaran bahasa Prancis dengan pendekatan komunikatif lebih menekankan pada pemerolehan kompetensi komunikatif. Kompetensi kebahasaan dimanifestasikan melalui pemberian wacana model yang mengandung bentuk dan makna berbagai tuturan (annoncés) grammatikal sesuai dengan konteksnya (Comité de la Coopération Culturelle, 2000, p.87). Namun demikian, berdasarkan tanggapan mahasiswa pada penilaian kinerja dosen pengampu mata kuliah Grammaire III pada aspek metode dan alat bantu pembelajaran diperoleh nilai cukup dengan penyataan bahwa dengan metode induktif pembelajaran kurang menarik dan kurang memberikan kejelasan tentang materi yang dipelajari, sedangkan media dan alat bantu pembelajaran dinyatakan kurang memadai. Kebutuhan media dan alat bantu belajar yang memadai untuk mahasiswa dapat difahami karena ilustrasi yang ada pada buku ajar tidak selalu memadai untuk penguasaan tata bahasa Prancis. Fakta ini berdampak pada adanya sebagian mahasiswa yang kurang menguasai tata bahasa Prancis yang telah dipelajari. Hal ini ditunjukkan masih adanya nilai $\mathrm{C}$ pada hasil ujian akhir semester gasal tiga tahun terakhir, yaitu tahun ajaran 2008/2009 sampai dengan 2010/2011, sebesar 22\% dari 72 mahasiswa, 10\% dari 52 mahasiswa dan 21\% dari 66 mahasiswa. Dengan demikian, salah satu upaya untuk meningkatkan penguasaan tata bahasa Prancis mahasiswa adalah terwujudnya penelitian untuk meningkatkan penguasaan kala lampau bahasa Prancis, karena concordance des temps $d u$ passé merupakan $\pm 20 \%$ dari keseluruhan aspek yang diukur.
Terkait dengan tanggapan mahasiswa dan pembelajaran tata bahasa pada buku ajar yang digunakan, permasalahan yang kemukakan pada penelitian ini, yaitu: (1) pembelajaran kala lampau bahasa Prancis dengan metode induktif masih berdampak pada adanya mahasiswa masih mendapati kesulitan menemukan dan menyimpulkan makna dan fungsi kala lampau bahasa Prancis dalam wacana yang pelajari; (2) kurangnya ilustrasi lambang visual pendukung pemahaman kala lampau dalam buku ajar yang digunakan menyebabkan adanya mahasiswa yang mendapati kesulitan untuk menciptakan pencitraan filmis tentang fungsi imparfait; (3) kurangnya penguasaan kala lampau bahasa Prancis mahasiswa apabila penjelasan materi perkuliahan disampaikan hanya secara verbalisme; (4) sebagian mahasiswa kurang dapat belajar mandiri karena kurangnya software pembelajaran kala lampau bahasa Prancis berbasis komputer di Jurusan Pendidikan Bahasa Prancis.

Berdasarkan permasalahan yeng ditemukan, dan tersedianya laboratorium bahasa di Fakultas Bahasa dan Seni Universitas Negeri Yogyakarta serta pemilikan komputer mahasiswa, solusi yang dipilih untuk meningkatkan penguasaan kala lampau bahasa Prancis mahasiswa adalah memproduksi multimedia pembelajaran agar mahasiswa dapat belajar secara mandiri untuk meningkatkan penguasaannya. Oleh karena itu, melalui penelitian ini diharapkan dapat dihasilkan multimedia pembelajran yang layak bagi mahasiwa Jurusan Pendidikan Bahasa Prancis FBS UNY dan produk tersebut dapat meningkatkan penguasaan kala lampau bahasa Prancis mahasiswa.

Kala lampau bahasa Prancis (imparfait/passé-composé) merupakan salah satu topik bahasan dalam matakuliah ini. Kedua kala lampau ini digunakan untuk memaparkan suatu peristiwa dan pengalaman. (Peyroutet, 1991, p.114). Pembelajaran imparfait/passé-composé meliputi aspek semantik dan kelancaran penggunaannya (Girardet, 2004, p.10). Imparfait digunakan untuk: (1) mendeskripsikan situasi/ 
keadaan yang melatari suatu peristiwa; (2) mendeskripsikan peristiwa minor yang melatari peristiwa mayor (peristiwa yang diungkapkan dengan passé-composé), dan (3) mengungkapkan kebiasaan pada masa lalu (Delatour, 2004, p.123). Descotesgenou (1996, p.180) menjabarkan deskripsi situasi yang melatari suatu peristiwa itu meliputi deskripsi tentang: cuaca, waktu, suasana, tempat dan sekitarnya, tokoh dan hal yang sedang dilakukannya. Oleh karena produk yang dihasilkan berfungsi sebagai sumber belajar pendukung pembelajaran matakuliah Grammaire III yang menggunakan metode induktif pada proses perkuliahannya, maka multimedia pembelajaran yang dihasilkan menggunakan metode deduktif untuk pembelajaran kala lampau bahasa Prancis. Hal ini dilakukan karena makna dan fungsi imparfait merupakan bahasan yang memerlukan penjelasan dan penerapan sehingga untuk mencapai peningkatan penguasaannya dalam waktu yang relatif diperlukan metode deduktif (Suparman, 2001, p.185).

Multimedia merupakan bagian dari media yang dapat digunakan sebagai sumber belajar bagi mahasiswa. Multimedia merupakan kombinasi dan beragam media yang mengandung unsur teks, grafik, gambar, animasi, suara dan video. (Hackbarth, 1996, p.228), Philips (1997, p. 8) juga berpendapat bahwa: "The multimedia component is characterized by the presence of text, picture, sound, animation and video, some or all which are organized into coherent program". Penggabungan dan beragam media tersebut dikemas dalam satu kesatuan yang secara bersama-sama menampilkan informasi, pesan atau isi pelajaran. Berdasarkan sifatnya, multimedia interaktif yang dihasilkan merupakan suatu multimedia interaktif yaitu multimedia yang dilengkapi dengan alat pengontrol yang dapat dioperasikan oleh pengguna sehingga pengguna dapat memilih isi media yang dikehendaki untuk proses selanjutnya (Vaughan, 2006, p.3). Dengan komputer sebagai alat bantu pengoprasiannya, interaktivitas yang tinggi, yakni memperhatikan, mendengarkan, menjelajah, merefleksi informasi yang telah diprogram dalam software, dan pelaksanaannya dikontrol oleh mahasiswa. Dengan demikian, sebagai multimedia interaktif, multimedia pembelajaran yang dihasilkan merupakan produk pembelajaran yang: (1) berbasis komputer, (2) interaktif, yakni memberi kesempatan kepada mahasiswa untuk melakukan respon dan mencoba simulasi, (3) fleksibel, yaitu memberi keleluasaan kepada mahasiswa untuk memilih materi dan menggunakannya.(4) individual dan self-facing, yakni memberi kesempatan kepada mahasiswa untuk belajar sesuai dengan kecepatannya dalam memahami materi, (5) memberikan informasi yang kaya dengan hadirnya even budaya yang dikemas dalam video.

Lebih lanjut, Philips (1997, p.11) menekankan bahwa pemanfaatan teknologi multimedia interaktif sebagai salah satu saran pembelajaran bagi mahasiswa mempunyai beberapa kekuatan dasar. Pertama, Mixed Media yakni mengintegrasikan berbagai media konvensional yang ada ke dalam satu jenis media interaktif. Contohnya, media teks, audio dan video yang jika dipisahkan membutuhkan banyak media. Kedua, User Control yaitu memungkinkan pengguna menelusuri materi ajar sesuai dengan kemampuan dan latar belakang pengetahuan yang dimilikinya, selain itu pengguna lebih nyaman dalam mempelajari isi media bila mereka melakukan pengulangan. Ketiga, Simulation and Visualization. Simulasi dan visualisasi merupakan fungsi khusus yang dimiliki oleh multimedia interaktif, sehingga dengan teknologi animasi, simulasi dan visualisasi pengguna akan mendapatkan informasi yang lebih riil dan informasi yang bersifat abstrak. Dengan demikian mahasiswa mampu mengembangkan mental dalam aspek kognitifnya. Keempat, Different Learning Style. Multimedia interaktif mempunyai potensi untuk mengakomodasi pengguna dengan gaya belajar yang berbeda-beda. Untuk memproduksi multimedia pembelajaran yang memiliki manfaat sebagaimana yang dipaparkan oleh Philips, multimedia 
yang dihasilkan memanifestasikan komunikasi komunikasi visual, audio visual.

Elemen komunikasi visual dalam pembuatan multimedia pada intinya mencakup: layout, tipografi, gambar dan ilustrasi, warna, animasi dan video Desain layout dibuat bertujuan memberikan nilai tambah terhadap aspek komunikatif multimedia pembelajaran agar mampu mempermudah informasi yang kompleks untuk dipahami (Philips, 1997, p.79). Untuk membuat layout dapat dibuat grid system, yaitu pembagian bidang sesuai dengan fungsi masing-masing elemen dalam komunikasi visual. Tipografi merupakan segala kegiatan dalam mengolah informasi yang sifatnya verbal menjadi bentuk visual termasuk didalamnya pemilihan font agar mudah dibaca dan bersifat spesifik. Pada dasarnya huruf dipilih guna mempresentasikan pengertian tersurat (untuk kebenaran pesan) huruf sebagai isi pesan verbal dan pengertian tersirat (untuk citra pesan) huruf sebagai penampilan visual. verbal, oleh karena itu huruf yang dipilih hendaknya memenuhi kriteria readable, legible dan clarity (Alessi \& Trollip, 2001, p.63).

Warna memiliki fungsi secara fisik dan psikologis. Warna berfungsi secara fisik, jika dalam penampilannya mampu memperjelas indera penglihatan dalam menangkap objek yang disajikan. Warna berfungsi psikologis, jika penampilannya menghasilkan perasaan tertentu. Dengan demikian pemilihan warna sebaiknya didasari oleh konsep kreatif yang telah ditetapkan sesuai topik pembelajaran dan penggunaan warna harus konsisten (Alessi \& Trollip, 2001, p.76).

Gambar merupakan elemen komunikasi visual berupa foto, ilustrasi atau drawing, diagram, serta elemen grafis yang lainnya seperti icon, navigasi, garis, box, splash, dan lain sebagainya. Gambar adalah bahasa visual yang bisa dimanfaatkan pada saat bahasa verbal dianggap kurang mampu untuk mempresentasikan pesan yang bersifat abstrak. Pesan abstrak akan menjadi nyata jika disajikan dalam wujud gambar.
Animasi artinya menghidupkan gambar yang mati, menggerakkan gambar yang diam dengan cara membuat metamorfosa dari bentuk semula ke bentuk selanjutnya dalam durasi tertentu. Video adalah menangkap obyek yang bergerak untuk selanjutnya disimpan dalam rangkaian foto yang diam dan diputar kembali menjadi gerak sesuai durasi yang dikehendaki. Perbedaan prinsip kerja inilah yang dapat dieksplorasi dan dimanfaatkan untuk mendukung penyajian materi ajar berbasis multimedia. Video cocok untuk menyajikan realitas sedangkan animasi cocok untuk menciptakan realitas dan sesuatu yang abstrak yang tidak mampu ditangkap oleh realitas visual (Alessi \& Trollip, 2001, p.72).

Adapun komunikasi audio adalah proses yang berhubungan dengan indera pendengaran. Audio dapat menampilkan pesan yang memotivasi dan menarik perhatian mahasiswa untuk mempelajari materi lebih banyak dan mendukung sistem pembelajaran tuntas (mastery learning) (Arsyad, 2007, p.149). Dalam multimedia pembelajaran berbasis unsur audio tidak dapat dipisahkan dengan unsur visual. Oleh karena itu, produk yang dihasilkan menggunakan unsur audio yang digabung dengan unsur gambar pada video untuk menyampaikan informasi tentang esensi persoalan yang berkaitan dengan materi yang diajarkan melalui multimedia pembelajaran. Unsur audiovisuel merupakan unsur penarik perhatian mahasiswa agar menyimak isi pesan yang dikomunikasikan dengan cara menghadirkan theatre of mind agar isi materi ajar lebih dihayati oleh mahasiswa.

Dua teori pembelajaran yang melandasi pengembangan multimedia pembelajaran kala lampau bahasa Prancis adalah teori belajar kognitif yang dikemukakan oleh Asubel dan teori pemrosesan informasi. Teori kognitif yang dikemukakan boleh Ausubel memusatkan perhatiannya pada konsepsi bahwa perolehan dan retensi pengetahuan baru merupakan konsepsi tentang struktur kognitif dalam merancang pembelajaran, yaitu struktur 
organisasional yang ada dalam ingatan seseorang selagi mengintegrasikan unsurunsur pengetahuan yang terpisah ke dalam suatu unit konseptual. Dengan demikian, belajar merupakan asimilasi materi yang dipelajari dengan pengetahuan yang sudah dimiliki dengan dalam bentuk struktur kognitif. Oleh karena itu dalam proses belajar lebih banyak ditekankan cara berfikir deduktif. Hal inilah yang mendasari pemilihan metode deduktif digunakan dalam media pembelajaran yang dihasilkan. Proses pembelajaran ini terjadi melalui tahap: memperhatikan stimulus, memahami makna stimulus, menyimpan dan menggunakan informasi yang sudah dipelajari (Budiningisih, 2005, p.51). Terkait dengan tahap-tahap proses pembelajaran tersebut penerapan langkah-langkah pembelajaran yang dikemukakan Ausubel dlakukan dalam produk multimedia yang dihasilkan. Oleh karenanya langkah langkah yang dilakukan, yaitu: (1) menentukan Kompetensi Dasar pembelajaran kala lampau bahasa Prancis, (2) mengidentifikasi karakteristik belajar mahasiswa, (3) penyajian kala lampau dengan muatan leksikal sampai dengan standar kompetensi berbahasa Prancis Niveau A 2 dengan konsep bentuk, makna dan fungsi, (4) tahapan pembelajaran dilaksanakan dengan alur topik: konjugasi imparfait, tiga makna pokok imparfait penanda informasi terkait dengan makna imparfait serta concordance des temps du passé, (5) konsep inti dikemas dengan ilustrasi gambar dengan tema: aktivitas sehari-hari, panorama alam, pakaian tradisional dan kenangan masa kanak-kanak serta video Jogja Java Carnival (Dinarto, 2010) dan Batik Solo Carnival (Menricomin, 2011), (6) keharusan belajar ulang apabila belum mencapai $75 \%$ dari skor total pada menu evaluasi produk multimedia pembelajaran yang dihasilkan.

Teori pemrosesan informasi merupakan teori belajar kognitif yang memfokuskan pada memori dan proses-proses penyimpanan. Teori ini menjelaskan bahwa setelah ada stimulus berupa informasi dari lingkungan dan respon oleh register penginderaan, ada tahap pemro- sesan, penyimpanan dan pemanggilan kembali informasi yang telah didapatkan dari otak untuk digunakan kembali bila dibutuhkan. Fungsi utama pikiran adalah memroses informasi dan memilah sesuai degan maknanya. Proses ini ditentukan oleh kaidah dan prinsip yang digunakan., Oleh karena itu, belajar dipandang sebagai aktivitas menyediakan kaidah-kaidah dan prisip-prinsip, dan kemudian menjadikan mampu mengaplikasikan sesuai dengan kaidah-kaidahyang tersedia. Dalam hal ini, pikiran pembelajar selagi belajar dipandang sebagai prosesor dengan short-term memory dan long-term memory termasuk di dalamnya working memory. Input diterima melalui sensory register. Input-input ini diproses oleh working memory sebagaimana fungsi RAM pada komputer dan setelah itu di simpan ke dalam long-term memory sebagaimana fungsi hard disc (Tan \& Loong dalam Chee \& Wong, 2003, p.80). Penerapan model pemrosesan informasi dalam pengembangan produk yang dihasilkan meliputi: (1) input yang dipaparkan yaitu bentuk,makna dan fungsi imparfait serta concordance des temps du passé, (2) senrory register untuk persepsi visual berupa informsi tektual dan ilustrasi gambar, audiovisual berupa paparan video dengan narasi peristiwanya, (3) attention dimanifestasikan melalui model presentasi, layout, warna, ilustrasi gambar pendukung teks, navigasi, (4) working memory memroses input dan input disimpan dalam long-term memory sebagimana fungsi hard disc.

\section{Metode}

\section{Model Pengembangan}

Penelitian ini merupakan penelitian dan pengembangan (Research and Development) yang diadopsi dari model pengembangan multimedia for learning dari Alessi dan Trollip, yaitu model pengembangan multimedia yang berorientasi pada software pembelajaran. Penelitian ini mengunakan pendekatan kuantitatif, dan data kuantitatifnya ada yang dikonversikan ke dalam data kualitatif untuk menentukan kualitas produk yang dihasilkan. Penelitian dan 
pengembangan ini dilakukan pada semester gasal tahun ajaran 20012/2013, di Fakultas Bahasa dan Seni Universitas Negeri Yogyakarta (FBS UNY).

\section{Subjek Penelitian}

Subjek penelitian ini adalah mahasiswa semester III Jurusan Pendidikan Bahasa Prancis FBS UNY yang mengikuti perkuliahan Grammaire III. Teknik sampling yang digunakan adalah sampel purposif. Mahasiswa semester III kelas A adalah rombel 1 sebagai responden kelas uji coba produk dengan jumlah 16 orang, sedangkan mahasiswa semester III kelas B adalah rombel 2 sebagai responden kelas pembanding dengan jumlah 17 orang.

\section{Prosedur Pengembangan}

Prosedur penelitian dan pengembangan ini mengacu pada model Alessi \& Trolip. (2001, p.410) dengan melalui 3 tahap, yaitu perencanaan (planning), desain (design) dan pengembangan (development). Modifikasi dengan penyederhanaan pada langkah-langkah dari ketiga tahapan ini dilakukan karena produk yang dihasilkan dirancang untuk memenuhi kebutuhan kalangan sendiri. Pertama, pada tahap perencanaan ini terdapat 5 langkah yaitu: (1) menetapkan ruang lingkup kajian (define the scope), (2) mengidentifikasi karakteristik mahasiswa (identify learner characteristics), (3) membuat dokumen perencanaan (produce a planning document), (4) menentukan dan mengumpulkan sumber (determine and collect resources), (5) melakukan brainstorming (conduct initial brainstorming).

Kedua, pada tahap desain, aktivitas yang dilakukan terkait dengan pengaturan isi dan menentukan hal-hal yang akan dilakukan dan dalam proses pembelajaran dan perspektif interaktifnya. Tahap ini meliputi 2 langkah yaitu: (1) melakukan analisis konsep dan tugas (conduct task and concept analyses), (2) membuat flowcharts dan story boards (create flowcharts and storyboards).

Ketiga, yang dilakukan pada tahap pengembangan adalah menuangkan desain program multimedia dalam bentuk pro- duk. Tahap ini meliputi 9 langkah, yaitu: (1) menyiapkan teks (prepare the text), (2) menggabungkan bagian (assemble the pieces), (3) menyiapkan materi pendukung (prepare support material), (4) membuat program, (5) melakukan uji alfa (do an alpha test), (6) membuat revisi (make revisions) (7) melakukan uji beta (do a beta test), (8) membuat revisi akhir (make final revisions), (9) memvalidasi program (validate) dengan uji coba produk.

Jenis Data

Data yang dikumpulkan terdiri dari dua jenis data, yaitu data kualitas multimedia pembelajaran yang dihasilkan dan data hasil belajar mahasiswa. Jenis data tentang kualitas multimedia pembelajaran yang dikembangkan adalah data kuantitatif yang dikonversikan ke dalam data kualitatif dengan skala likert. Data ini mencakup aspek pembelajaran, isi/materi, tampilan navigasi dan ketahanan produk serta informasi tambahan. Jenis data yang diperoleh dari hasil belajar mahasiswa adalah data kuantitatif, yakni skor pretest dan posttest. Untuk memperoleh skor tersebut dilakukan prosedur berikut.

Pertama, tahap pravalidasi produk, yakni tahap persiapan sebelum dilaksanakan uji coba produk. Tahap ini meliputi penyusunan instrument tes penguasaan kala lampau bahasa Kedua, tahap uji coba produk yang meliputi 3 langkah, yaitu: pretest, pelaksanaan validasi produk dihasilkan, dan posttest. Pretest diberikan kepada kedua rombel responden untuk mengetahui skor awal mahasiswa tersebut. Pelaksanaan validasi produk yang dihasilkan merupakan perkuliahan diikuti oleh mahasiswa rombel 1 dengan menggunakan CD interaktif sedangkan perkuliahan dengan bahasan yang sama untuk mahasiswa rombel 2 dilaksanakan tanpa produk pembelajaran tersebut. Posttest diberikan setelah perkuliahan, dan bertujuan untuk mengetahui tingkat pencapaian penguasaan kala lampau bahasa Prancis mahasiswa dari kedua rombel tersebut, dan menggunakan perangkat yang sama dengan pelaksanaan pretest. Ketiga, tahap pasca- 
validasi produk. Pada tahap ini data pretest dan posttest dianalisis untuk mengetahui besaran peningkatan penguasaan kala lampau bahasa Prancis kedua rombel tersebut sehingga diketahui keefektifan produk pembelajaran yang dihasilkan.

\section{Instumen dan Teknik Pengumpulan Data}

Instrument yang digunakan pada penelitian ini berupa kuesioner, wawancara, dan tes hasil belajar mahasiswa. Kuesioner untuk ahli materi, ahli media dan mahasiswa digunakan untuk memperoleh data kualitas multimedia pembelajaran yang dihasilkan.Kuesioner untuk ahli materi berkaitan dengan 4 aspek yaitu aspek pembelajaran dengan 20 indikator, materi dengan 30 indikataor, informasi tambahan dengan 2 indikator dan tampilan dengan 6 indikator (Alessi \& Trollip, pp. 2001, pp.414-419, 422-429, 565, 566). Kuesioner untuk ahli media meliputi tampilan navigasi, informasi tambahan, ketahanan produk dan pedagogi. Kisi-kisi lembar kuesioner untuk mengevaluasi produk oleh ahli media meliputi 5 aspek, yaitu: aspek tampilan dengan 13 indikator, navigasi dengan 5 indikator, informasi tambahan dengan 2 indikator, ketahanan produk dengan 2 indikator, dan pedagogi dengan 4 indikator (Alessi \& Trollip. 2001, pp.422428, 431, 567). Kuesioner untuk mahasiswa, meliputi 3 aspek, yaitu: pembelajaran dengan 5 indikator, materi dengan 5 indikator, dan media dengan 10 indikator (Alessi \& Trollip, 2001, pp.418, 422-427, 431, 566-567).

Wawancara dilakukan dengan sembilan mahasiswa yang menjadi subjek coba penelitian, ahli media, dan ahli materi. Wawancara yang dilakukan adalah wawancara bebas terpimpin. Oleh karena itu, hanya dipersiapkan kisi-kisi pertanyaan yang disampaikan untuk mendapatkan gambaran yang jelas tentang informasi yang diperoleh dari lembar kuesioner yang telah mereka isi dan tanggapan mereka tentang produk yang dikembangkan.

Tes pilihan ganda terdiri dari empat puluh butir soal digunakan untuk memperoleh data hasil belajar mahasiswa tentang kala lampau bahasa Prancis yang meliputi bentuk dan fungsi imparfait dan concordance des temps: imparfait / passécomposé. Sebelum instrumen tes digunakan untuk mengambil data hasil belajar mahasiswa dilakukan pengukuran validitas dan reliabilitas soal. Uji coba soal dilakukan terhadap mahasiswa Jurusan pendidikan Bahasa Prancis yang pernah mengambil mata kuliah Grammaire III. Analisis validitas dan reliabilitas soal dilakukan dengan menggunakan program ITEMAN (Sukardjo, 2009, p.122). Terkait dengan ketuntasan belajar (mastery learning) pada penelitian ini digunakan kriteria penguasaan kala lampau bahasa Prancis sebesar $\geq 70 \%$ dari tujuan yang harus dikuasai oleh mahasiswa (Suparman. 2005, p.137).

\section{Teknik Analisis Data}

Teknik analisis data yang dilakukan yaitu menganalisis data yang terkumpul secara kuantitatif dan kualitatif, yakni: (1) data kuantitatif yang diperoleh dari kuesioner dan wawancara dianalisis dan dikonversikan ke data kualitatif dengan skala 5 (skala likert), kemudian dideskripsikan untuk mengetahui kualitas media yang dikembangkan; (2) data kuantitatif yang diperoleh dari tes hasil belajar yang diperoleh dihitung dengan menggunakan rumus gain score. Gain score merupakan indikator yang baik untuk menunjukkan tingkat efektivitas pembelajaran yang dilakukan melalui skor pretest dan posttest (Hake, 1999, p.1). Oleh karena itu dengan menggunakan rumus gain score pada penelitian ini akan diketahui bahwa penggunaan media pembelajaran dalam bentuk CD interaktif yang dihasilkan dapat mengoptimalkan struktur kognitif mahasiswa dalam mempelajari kala lampau bahasa Prancis.

\section{Hasil Penelitian dan Pembahasan}

Hasil Validasi dan Saran Revisi Produk

Proses pengembangan media pembelajaran dengan target pengguna adalah mahasiswa semester III Jurusan Pendidikan Bahasa Perancis dimulai setelah semua 
materi dan bahan pendukung seperti video, konsep animasi dan sound dinyatakan siap untuk dituangkan dalam bentuk produk awal. Adapun program yang digunakan dalam proses pembuatan produk ini adalah Macromedia Flash 8 dan Sonny Vegas Pro 8. Proses pembuatan program tersebut didasarkan pada flowchart dan storyboard yang telah dipersiapkan serta kesiapan bahan-bahan yang telah dipersiapkan sesuai dengan karakteristik pengguna. Untuk mengurangi kesalahan yang dapat terjadi pada saat proses produksi makadilakukan review flowchart dan storyboard yang dibuat oleh ahli materi dan ahli media. Proses pembuatan program diakhiri dengan mengkaji kembali produk yang dihasilkan dengan mencoba menjalankan program. Bila tidak lagi ditemukan kesalahan, maka produk siap untuk dilakukan uji coba. Uji coba produk dilakukan dengan 3 tahapan yaitu uji alpha, uji beta dan uji coba produk. Hasil akhir produk awal dikemas dalam bentuk compact disk dengan garis besar berisi: (1) Kompetensi Dasar yang harus dikuasai mahasiswa setelah mempelajari materi yang termuat di dalam CD, (2) materi yang berisi tentang kala lampau dalam bahasa Perancis imparfait, passé-composé. Pada setiap akhir penyajian materi diberikan latihan soal guna mengukur ketuntasan belajar mahasiswa. Tingkat kemajuan belajar mahasiswa ditentukan oleh keberhasilan mereka dalam mengerjakan soal latihan yang tersedia. (3) Evaluasi berisi soal-soal untuk mengukur tingkat pemahaman materi yang disajikan setelah mahasiswa mempelajari kala lampau bahasa Prancis dengan media pembelajaran yang dikembangkan. (4) Bahan penarik perhatian berupa gambar, video, animasi dan sound. (5) Pengembang berisi tentang identitas pengembang, ahli media dan ahli materi. Uji Alpha dilakukan bertujuan untuk menguji kualitas media pembelajaran oleh ahli materi dan ahli media. Hasil validasi digunakan untuk membuat revisi pertama terhadap produk yang dikembangkan. Hasil validasi ahli materi diperoleh dengan memberikan produk dalam bentuk Compact Disk (CD) dan lem- bar validasi dalam bentuk kuisioner dengan acuan skala likert. Lembar kuesioner oleh ahli materi termuat dalam 4 aspek, yaitu aspek: pembelajaran, materi, informasi tambahan, dan tampilan. Secara ringkas hasil validasi ahli materi terhadap CD interaktif yang dikembangkan disajikan pada Tabel 1.

Tabel 1. Rekap Rerata Skor Hasil Validasi Ahli Materi pada Uji Alpha.

\begin{tabular}{clcc}
\hline No. & \multicolumn{1}{c}{ Indikator } & Skor & Kriteria \\
\hline 1 & Pembelajaran & 4,65 & Baik \\
2 & Materi & 4,50 & Baik \\
3 & Informasi Tambahan & 5,00 & $\begin{array}{c}\text { Sangat } \\
\text { Baik }\end{array}$ \\
\multicolumn{2}{c}{$\begin{array}{c}\text { Tampilan } \\
\text { Rerata }\end{array}$} & 4,66 & $\begin{array}{c}\text { Baik } \\
\text { Taik }\end{array}$ \\
$\begin{array}{l}\text { Kriteria Kualitas Media Pem- } \\
\text { belajaran oleh Ahli Materi }\end{array}$ & Baik \\
\hline
\end{tabular}

Pada tabel 1 tampak secara umum kualitas media pembelajaran yang dikembangkan dalam kriteria baik dengan rerata skor sebesar 4,70. Demi perbaikan produk yang dihasilkan diperlukan perbaikan pada aspek pembelajaran dan materi. Data deskriptif dari ahli materi dalam bentuk komentar dan saran sebagai dasar untuk membuat revisi pertama terhadap produk yang dikembangkan. Komentar dari ahli materi yaitu bahwa: (1) CD interaktif yang dikembangkan memiliki ciri khas yang sekaligus menjadi kelebihannya ada pada interaktivitas saat mempelajari materi yang disajikan, (2) kekurangan CD interaktif yang dikembangkan terdapat pada volume narasi pada video kurang keras sehingga pengguna harus menggunakan headset, (3) $C D$ ini tepat digunakan untuk sumber belajar mahasiswa secara mandiri sebagai pendamping sekaligus pelengkap materi pada sumber belajar yang diwajibkan,dan bukan untuk menggantikan tatap muka antara dosen dengan mahasiswa.

Hasil validasi ahli media pembelajaran diperoleh dengan memberikan produk dalam bentuk Compact Disk (CD) dan lembar validasi dalam bentuk kuisioner dengan acuan skala likert. Lembar kuesioner oleh ahlimedia termuat dalam 4 aspek 
yaitu aspek: tampilan, navigasi, informasi tambahan, ketahanan produk dan pedagogi. Secara ringkas rekap rerata hasil validasi oleh ahli media terhadap CD interaktif yang dihasilkan disajikan pada Tabel 2.

Tabel 2. Rekap Rerata Hasil Validasi Ahli Media pada Uji Apha.

\begin{tabular}{clcc}
\hline No. & \multicolumn{1}{c}{ Indikator } & Skor & Kriteria \\
\hline 1 & Tampilan & 3,69 & Cukup \\
2 & Navigasi & 4,00 & Baik \\
3 & Informasi tambahan & 4,00 & Baik \\
4 & Ketahanan produk & 4,00 & Baik \\
5 & Pedagogi & 4,00 & Baik \\
Rerata & \multicolumn{2}{c}{3,94} \\
\hline Kriteria Kualitas Media \\
oleh Ahli Media
\end{tabular}

Pada Tabel 2 tampak secara umum kualitas media pembelajaran yang dikembangkan dalam kriteria baik dengan rerata skor sebesar 3,94. Demi perbaikan produk yang dihasilkan diperlukan perbaikan pada aspek tampilan karena berkriteria cukup. Data deskriptif dari ahli media dalam bentuk komentar dan saran sebagai dasar untuk membuat revisi pertama terhadap produk yang dikembangkan, yaitu: (1) CD interaktif yang dikembangkan mudah dioperasikan, namun ilustrasi gambar untuk program video masih kurang sehingga masih seperti produk buku cetak, (2) video mestinya menjadi satu (built in) dengan menu materi, tidak berdiri sendiri.

Dengan demikian bersumber dari hasil validasi ahliproduk yang dikembangkan termasuk dalam kategori baik pada uji alpha dengan perolehan rerata skor 4,22, dengan rincian: (1) aspek tampilan sebesar $4,31(14,4 \%)$, (2) aspek materi sebesar 4,50 $(15 \%)$, (3) aspek navigasi sebesar 4,0 $(13,3 \%),(4)$ aspek ketahanan produk sebesar 4,0 (13,37\%), (5) aspek pedagogi sebesar 4,0 (13,37\%), (6) aspek informasi tambahan sebesar 4,50 (15\%), dan (7) aspek pembelajaran 4,65 (15,5\%). Visualisasi kualitas produk secara keseluruhan pada uji alpha dapat dilihat pada Gambar 1 .

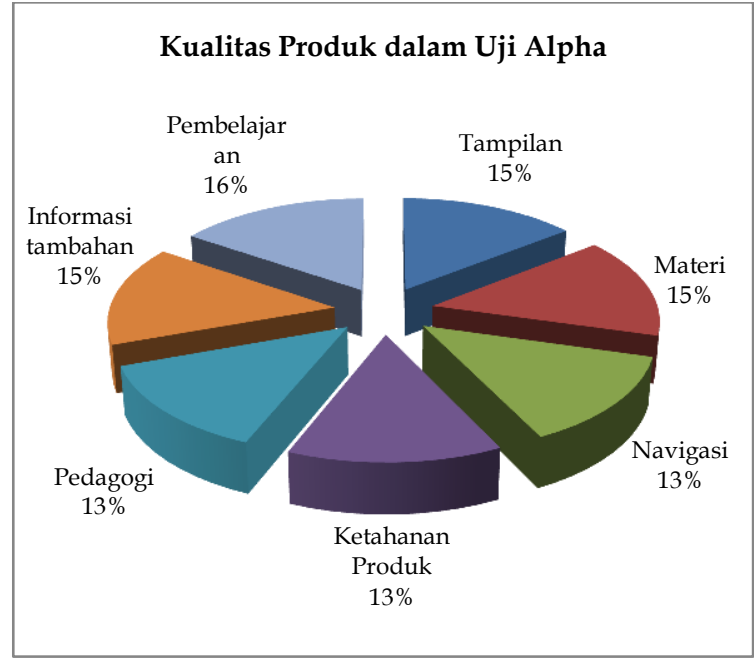

Gambar 1. Kualitas Produk dalam Uji Alpha.

Hasil Validasi dan Saran Revisi Produk

\section{Uji Beta}

Uji beta dilakukan dengan tujuan untuk mengetahui tanggapan mahasiswa terhadap media pembelajaran yang dikembangkan berpusat pada keberfungsian program. Pada lembar kuesioner untuk mahasiswa termuat 3 aspek, yaitu: aspek pembelajaran, aspek materi dan aspek media Responden uji beta adalah mahasiswa semester V Jurusan Pendidikan Bahasa Prancis FPBS Universitas Negeri Yogyakarta. Mahasiswa berjumlah 9 orang dengan rincian 3 orang mahasiswa yang mempunyai kemampuan tinggi (di atas rata-rata), 3 orang mahasiswa berkemampuan sedang (rata-rata) dan 3 orang lainnya berkemampuan rendah (di bawah rata-rata). Tingkat kemampuan mahasiswa ditentukan oleh IPK (Indeks Prestasi Kumulatif) yang dimiliki mahasiswa dan nilai mata kuliah prasyarat minimal B. Secara ringkas rekap rerata hasil validasi oleh ahli media terhadap CD interaktif yang dihasilkan disajikan pada Tabel 3.

Pada tabel 3 nampak secara keseluruhan dari tanggapan mahasiswa terhadap kualitas media pembelajaran yang dikembangkan diperoleh rerata skor 4,12 dengan kriteria baik. Secara rinci perolehan skor sebagai berikut: (1) aspek pembelajaran dengan skor 4,07 (33,1\%), (2) aspek 
materi dengan skor 4,24 (34,5\%) dan (3) aspek media dengan skor sebesar 4,06 $(32,4 \%)$. Perolehan skor tersebut dapat divisualkan pada gambar 2 .

Tabel 3. Rekap Hasil Tanggapan Mahasisw terhadap Kualitas Media Pembelajaran Kala Lampau Bahasa Prancis pada Uji Beta.

\begin{tabular}{llcc}
\hline No & Indikator & Skor & Kriteria \\
\hline 1 & Pembelajaran & 4,07 & Baik \\
2 & Materi & 4,24 & Baik \\
3 & Media & 4,06 & Baik \\
& \multicolumn{2}{c}{4,12} \\
\hline \multicolumn{2}{c}{ Kriteria Tanggapan } & \multicolumn{2}{c}{ Baik } \\
Mahasiswa pada Uji Beta & \multicolumn{2}{c}{} \\
\hline
\end{tabular}

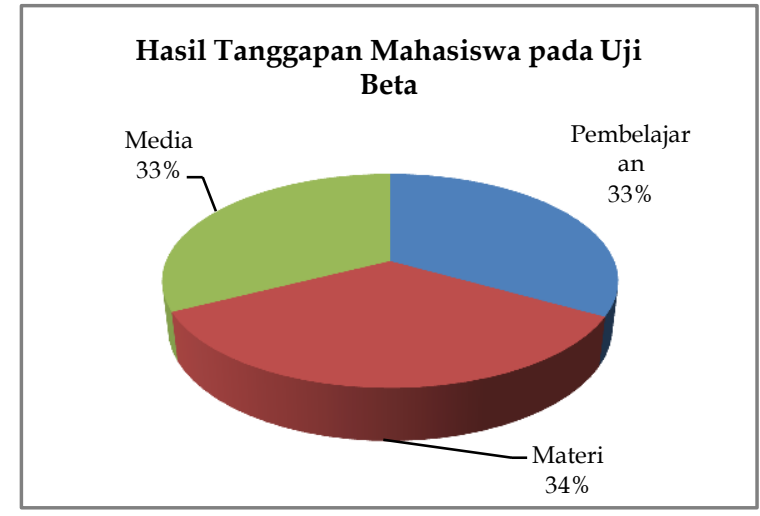

Gambar 2. Hasil Tanggapan Mahasiswa pada Uji Beta.

Komentar juga diberikan oleh mahasiswa pada saat mereka selesai mencoba menggunakan CD interaktif yang dikembangkan selama 3 jam. Seluruh mahasiswa menyatakan bahwa materi kala lampau bahasa Perancis lebih mudah dipahami karena adanya visualisasi dari fungsi imparfait. Konsep yang disajikan mudah diikuti: Mereka juga merasa terpacu untuk belajar lebih baik yang dibuktikan dengan adanya pernyataan bahwa 87,5 \% dari mereka harus mengulang materi demi mencapai ketuntasan belajar yang ditetapkan di dalam CD tersebut. Proses belajar kala lampau bahasa Perancis juga menjadi lebih menarik dan sesuai dengan media yang mereka butuhkan saat ini. mahasiswa tidak mengalami kesulitan untuk mengoperasikan CD pembelajaran yang dikembangkan.
Bersumber dari hasil 2 tahap evaluasi terhadap produk yang dihasilkan, dapat diketahui bahwa kualitas media pembelajaran yang dikembangkan mempunyai kualitas baik dari validasi oleh ahli media dan ahli materi maupun tanggapan mahasiswa sebagai pengguna produk. Ahli materi memberikan skor 4,70 dengan kriteria baik, ahli media memberikan skor 3,94 dengan kriteria baik, mahasiswa responden pada uji beta memberikan skor 4,12 pada uji beta. Berdasarkan perolehan rerata skor hasil validasi pada uji alpha dan uji beta produk yang dihasilkan dalam penelitian ini termasuk dalam kategori baik. Kategori tersebut dapat ditinjau dari tiga aspek, yakni: aspek pembelajaran dengan rerata skor 4,36 $(4,65: 4,07)$, aspek materi dengan rerata skor 4,37 $(4,50: 4,24)$ dan aspek media dengan rerata skor 4,00 $(3,94: 4,06)$.

\section{Hasil Revisi Produk}

Berdasarkan data deskriptif dari ahli materi dalam bentuk komentar dan saran dilakukan revisi pertama terhadap produk yang dikembangkan. Saran dari ahli materi yang sekaligus digunakan sebagai dasar revisi pertama, yaitu: (1) pembetulan ejaan pada tujuh kata: blouse, s'emploie, en inscrivant, ministre, soufflait, heure, courrier pada frames: 9, 10, 11 dan 15, (2) perbaikan layout untuk Quize 2 pada frames 45, (2) penambahan quize pada menu video dan (3) kelengkapan data profile pada frames: $73,74,75$.

Adapun data deskriptif dari ahli media dalam bentuk komentar dan saran sebagai dasar untuk membuat revisi pertama terhadap produk yang dikembangkan, yaitu: (1) CD interaktif yang dikembangkan mudah dioperasikan, namun ilustrasi gambar untuk program video masih kurang sehingga masih seperti produk buku cetak, (2) video mestinya menjadi satu (built in) dengan menu materi, tidak berdiri sendiri. Revisi pertama berdasarkan hasil validasi oleh ahli media, yaitu: (1) memindahkan menu video ke dalam menu materi, (2) menambahkan ilustrasi gambar 
pada frames 34 dan 50. Dengan demikian berdasarkan hasil proses uji alpha, telah dilakukan revisi: (1) pada frames: 9, 10, 11, $15,34,45$, 50; (2) penambahan data profil pada 73, 74,75; (3) penambahan quize pada menu video dan memindahaka menu video ke dalam menu materi.

Selanjutnya saran dari hasil proses validasi pada uji beta dijadikan dasar revisi kedua adalah: (1) penambahan variasi font dan warna pada teks. (2) penambahan penjelasan tentang benar dan salahnya suatu jawaban. Dengan demikian berdasarkan hasil proses uji beta, telah dilakukan revisi: (1) variasi font dan warna pada frames: 9 12, 27 - 32, 53 -71; (2) penambahan (2) penambahan penjelasan tentang benar dan salahnya suatu jawaban pada frames: 39 41,45 -45 dan 47 -49.

\section{Uji Coba Produk}

Uji coba produk dengan tujuan untuk mengetahui hasil belajar yang diperoleh mahasiswa setelah menggunakan CD interaktif yang dihasikan. Validasi produk dilakukan terhadap mahasiswa semester III Jurusan Pendidikan Bahasa Perancis Fakultas Bahasa dan Seni Universitas Negeri Yogyakarta. Prosedur uji coba produk dilakukan dengan 3 tahap. Pertama, tahap pravalidasi produk, yakni tahap persiapan sebelum dilaksanakan uji coba produk. Tahap ini meliputi penyusunan instrument tes penguasaan kala lampau bahasa Prancis yang valid dan reliabel dan penentuan kelas yang digunakan sebagai responden. Ada 2 kelas paralel yang masing-masing kelas terdiri dari 16 sampai dengan 17 mahasiswa. Dipilih satu kelas dari kelas yang ada sebagai responden validasi produk. Proses penentuan kelas dilakukan setelah diperoleh hasil belajar pada ujian tengah semester untuk mata kuliah Grammaire III. Dari proses penentuan kelas diperoleh hasil bahwa kelas 3 A, yakni rombongan belajar (rombel) 1 yang terdiri dari 16 mahasiswa, dipilih sebagai kelas uji coba produk yang dikembangkan karena rerata skor hasil ujian tengah semester mereka lebih rendah dibandingkan dengan kelas 3 B, yakni rombongan belajar 2, sebagai kelas pembanding yang terdiri dari 17 mahasiswa, yakni 64,3: 66,5.

Kedua, tahap uji coba produk yang meliputi 3 langkah, yaitu: pretest, pelaksanaan validasi produk dihasilkan, dan posttest. Pretest diberikan kepada kedua rombel responden untuk mengetahui skor awal mahasiswa tersebut. Pelaksanaan validasi produk yang dihasilkan merupakan perkuliahan diikuti oleh mahasiswa rombel 1 dengan menggunakan CD interaktif yang dihasilkan, dan dilakukan di laboratorium bahasa di gedung C 15 FBS UNY, sedangkan perkuliahan dengan bahasan yang sama untuk mahasiswa rombel 2 dilaksanakan tanpa produk pembelajaran tersebut. Posttest diberikan setelah perkuliahan, dan bertujuan untuk mengetahui tingkat pencapaian penguasaan kala lampau bahasa Prancis mahasiswa darikedua rombel tersebut, dan menggunakan perangkat yang sama dengan pelaksanaan pretest.

Ketiga, tahap pascavalidasi produk. Pada tahap ini data pretest dan posttest dianalisis untuk mengetahui besaran peningkatan penguasaan kala lampau bahasa Prancis kedua rombel tersebut sehingga diketahui keefektifan produk pembelajaran yang dihasilkan. Hasil belajar kala lampau dari kedua rombel pada Tabel 4 .

Tabel 4. Rekap Hasil Belajar Mahasiswa Responden Uji Coba Produk

\begin{tabular}{llcc}
\hline & & \multicolumn{2}{c}{ Responden } \\
No & \multicolumn{1}{c}{ Skor } & Rombel & Rombel 2 \\
& & 21 & 21 \\
\hline 1. & Terendah & 38 & 36 \\
2. & Tertinggi & 31,88 & 28,76 \\
3. & Rerata & 75 & 53 \\
4. & Ketuntasan (\%) & 30 & 7,7 \\
5. & Peningkatan Hasil & & \\
& Belajar (\%) & & \\
\hline
\end{tabular}

Tabel 4 menunjukkan bahwa perolehan rerata hasil belajar rombel 1 lebih tinggi dibanding dengan rombel 2 dengan perbedaan rerata hasil belajarnya sebesar 
3,12 (31,88: 28,76) dari perolehan skor posttest. Perbedaan persentase peningkatan hasil belajar dengan rombel yang tidak menggunakan media pembelajaran yang dihasilkan sebesar 22,3\%. Pengujian efektivitas penggunaan media pembelajaran yang dihasilkan dilakukan dengan rumus gain score. Hasil penghitungan dapat dilihat pada lampiran dan rekap hasil rerata gain score kelas uji coba dan kelas pembanding dapat dilihat pada Tabel 5.

Tabel 5. Rekap Hasil Rerata Gain Score Kelas Uji Coba dan Kelas Pembanding

\begin{tabular}{lcccc}
\hline Rombel & $\begin{array}{c}\text { Rerata } \\
\text { Pretest }\end{array}$ & $\begin{array}{c}\text { Rerata } \\
\text { Posttest }\end{array}$ & $\begin{array}{c}\text { Rerata } \\
\text { Gain score }\end{array}$ & Ket. \\
\hline Rombel 1 & 19,75 & 31,88 & 0,59 & Sedang \\
Rombel 2 & 25,65 & 28,76 & 0,28 & Rendah \\
\hline
\end{tabular}

Tabel 5 menunjukkan bahwa perolehan rerata gain score kelas uji coba sebesar 0,59 lebih besar dari 0,3 dan kurang dari $0,7(0,3<\mathrm{g}<0,7=0,3<0,59<0,7)$ termasuk dalam kategori sedang. Perolehan rerata gain score tersebut lebih besar dari pada rerata gain score kelas pembanding yang mempunyai rerata gain score sebesar 0,28 lebih kecil dari $0,3(\mathrm{~g}<0,3=0,28<0,3$ ) termasuk dalam kategori rendah. Hal ini menunjukkan bahwa penggunaan multimedia yang dihasilkan untuk meningkatkan penguasaan kala lampau bahasa Prancis pada perkuliahan kelas uji coba lebih efektif daripada perkuliahan kelas pembanding yang tidak menggunakan multimedia yang dihasilkan.

Kajian Produk Akhir

Berdasarkan paparan tersebut, maka media pembelajaran yang dihasilkan layak dijadikan sebagai sumber belajar mahasiswa semester III Jurusan Pendidikan Bahasa Prancis FBS UNY, karena: (1) media pembelajaran dihasilkan dengan langkahlangkah yang sudah dibakukan dengan dua tahap evaluasi yaitu uji alpha oleh ahli, uji beta oleh mahasiswa, (2) media pembelajaran yang dihasilkan mempunyai kualitas baik menurut ahli media, menurut ahli materi dan mahasiswa sebagai pengguna baik, (3) media pembelajaran ini juga memberikan kemudahan bagi mahasiswa untuk mengoptimalkan pemahaman konsep kala lampau bahasa Perancis pada struktur kognitif mereka.

Uji coba produk menunjukkan hasil yang positif dengan adanya peningkatan yang signifikan pada hasil belajar mahasiswa yang ditunjukkan dengan penghitungan gain score dan perolehan rerata gain score sebesar 0,59. Hal ini berarti bahwa upaya pengembangan multimedia pembelajaran yang dilakukan merupakan hal yang tepat. Adanya tahap revisi memberikan kualitas multimedia pembelajaran yang dihasilkan menjadi semakin baik ditinjau aspek materi, aspek media dan aspek ketahanan produk. Produk media yang dihasilkan didesain dengan navigasi linier, karena dalam materi kala lampau bahasa Prancis merupakan materi bersyarat yakni materi pertama menjadi prasyarat bagi materi kedua dan seterusnya. Media ini juga didesain dengan pemberian batas ketuntasan minimal $75 \%$ pada setiap latihan. Dengan demikian penguasaan terhadap materi menjadi lebih terkontrol.

Adapun spesifikasi dari media pembelajaran yang dihasilkan adalah adanya video dan animasi/ visualisasi dari proses suatu peristiwa.Visualisasi proses peristiwa dikemas dalam bentuk video dan didesain untuk mahasiswa. Hal ini merupakan suatu kelebihan dari media ini. Namun demikian dibalik kelebihan ada keterbatasan yang tidak dapat dihindari. Keterbatasan yang masih dijumpai adalah tidak semua proses suatu peritiwa divisualisasikan. Keterbatasan akan menjadi kelebihan bila penelitian pengembangan ini dilanjutkan pada peningkatan visualisasi proses suatu peristiwa yang difokuskan pada setiap materi.

\section{Simpulan dan Saran}

Simpulan

Berdasarkan hasil penelitian yang diperoleh dapat disimpulkan beberapa hal 
berikut. Pertama, secara keseluruhan CD interaktif pembelajaran kala lampau bahasa Prancis yang dihasilkan layak digunakan dan termasuk dalam kategori baik karena memperoleh: rerata skor dari ahli materi, ahli media pembelajaran dan mahasiswa sebesar 4,25. Berdasarkan perolehan rerata skor pada uji alpha dan uji beta tersebut dapat diperoleh tiga aspek yang dapat menjadi dasar kelayakan CD interaktif yang dihasilkan, yaitu: aspek pembelajaran dengan rerata skor 4,36, aspek materi dengan rerata skor 4,37, dan aspek media dengan rerata skor 4,00.

Kedua, pemanfaatan media pembelajaran yang dihasilkan dalam penelitian ini mampu: (1) meningkatkan hasil belajar kelompok mahasiswa kelas uji coba yang semula memiliki rerata skor pretest 19,75 menjadi 31,88 untuk rerata skor posttest; (2) membuktikan keefektifan penggunaan produk yang dihasilkan dengan pemerolehan skor rerata gain score sebesar 0,59 , sedangkan kelas pembanding memperoleh skor rerata gain score sebesar 0,28 ; (3) memberikan sumber belajar yang efisien dan adaptable. Efisien ditunjukkan dengan $75 \%$ mahasiswa mendapat skor $\geq 70$, yang semula pencapaian ketuntasan belajar pada pretest dicapai oleh 6\% mahasiswa. Adaptabel ditunjukkan dengan tanggapan mahasiwa bahwa media pembelajaran yang dihasilkan sesuai dengan karakteristik materi dan kebutuhan mereka.

Saran

Uji coba dalam penelitian ini masih sangat terbatas pada ruang lingkup yang sempit dengan sampel yang sangat kecil sehingga perlu diujicobakan dalam skala yang lebih luas dengan sampel yang lebih besar sehingga signifikasi penggunaannya jelas, lebih akurat dan lebih banyak aspek yang dapat diungkap dari dari uji coba tersebut. Pada tahap berikutnya, perlu pula produk dalam penelitian ini dibandingkan dengan produk-produk lain yang sejenis untuk mendapatkan standar kelayakan dan pemenuhan kualitas minimal yang sudah ditentukan.

\section{Daftar Pustaka}

Alessi, S. M. \& Trollip, S. R. (2001). Multimedia for learning: Methods and development. Boston: Allyn and Bacon.

Arsyad, A. (2009). Media pembelajaran Jakarta: Raja Grafindo Persada.

Budiningsih, A. (2005). Belajar dan pembelajaran. Jakarta: Rineka Cipta.

Comité de la Coopération Culturelle. (2000). Un cadre européen commun de références pour les langues. Strasbourg: Divisions des Langues Vivantes.

Delatour, Y. et al. (2004). Nouvelle grammaire. Paris: Hachette.

Descotes-genou. Ch. (1996). L'exercisier. Grenoble: PUG.

Dinarto, D. (2010). Carnaval PBTY 2010. http:www.youtube.com/devridinar to diambil pada 31 Maret 2011.

FBS. (2010) Kurikulum 2009: Program Studi Pendidikan Bahasa Prancis. Yogyakarta: UNY.

Girardet, J. \& Pécheur, J. (2004). Campus 2. Guide pédagogique. Paris: CLE International.

Hackbarth S. (1996). The educational technology handbook. New Jersey educational Technology Publication, Englewood Cliffs.

Hake, R. R. (1999). Analyzing change/gain Scores. Diakses tanggal 28 Nopember 2013 dari http: www.physics. indiana.edu/ sdi/analyzing change-gain.pdf

Menricomin. (2011). Solo batik carnival 2011. Diakses tanggal 3 April 2012 dari http://solobatikcarnival.com/.

Peyroutet. C. (1995). Style et rhétorique. Paris: Nathan.

Philips, R. (1997). The developer's handbook to interactive multimedia (A practical guide for educational applications. London: Kogan page. 
Sukardjo. (2009). Evaluasi pembelajaran / Perkuliahan bidang studi, Yogyakarta: Program Pascasarjana Universitas Negeri Yogyakarta.

Suparman, A. (2001). Desain instruksional: Mengajar di perguruan tinggi. Jakarta: PAU-PPAI, Universitas Terbuka.
Tan Seng Chee \& Angela F.L. Wong (Ed.), (2003). Teaching and learning with technology: an Asia pacific perspetive. Singapore: prentice Hall.

Vaughan, T. (2006). Multimedia: Making it work, Edisi 6. (Terjemahan Theresia Arie Prabawati \& Agnes Heni Triyuliana). Yogyakarta: Andi Offset. 